\title{
MANAJEMEN KURIKULUM BIDANG TEACHING AND LEARNING
}

\author{
Kisbiyanto
}

Jurusan Tarbiyah STAIN Kudus

\begin{abstract}
This organizing the curriculum areas of teaching and learning study applies qualitative approach. The goal is to (1) describe the plan of curriculum planning in the field of teaching and learning, (2) describe the syllabus of curriculum in the field of teaching and learning, and (3) describe the lesson plans of curriculum in the field of teaching and learning at Islamic Studies State College of Kudus (STAIN Kudus).

The results of this study are: (1) curriculum planning at STAIN Kudus approach is competence based, namely the approach to ensure subjects as teaching material oriented to the ability of learners / students, with three subjects of nuanced teaching and learning, namely Islamic Education System Planning, Learning Strategy of Islamic Education, Development of Islamic Education Evaluation System, (2) the syllabi of the three subjects allied the fields of teaching and learning but differed clearly from the aspect of its scope, however united integrative aspects of the mastery of methods and leaning techniques, (3) the lesson plans of the three subjects clumped the field of teaching and learning are prepared with components subject code, types of subjects, programs of study, undergraduate scholarship, the weight of credit semester system, many meetings fourteen times, time according to the weight of the credit, the standard of competence, basic competencies, indicators, subject matter, teaching methods, assessment systems, and learning resources.
\end{abstract}

Keywords: curriculum, research

\section{Pendahuluan}

\subsection{Latar Belakang Masalah}

Salah satu kendala umum dalam pengajaran adalah masalah kurikulum. Kurikulum yang statis akan menjadi materi didik yang tertinggal (out of date) dengan perkembangan sosial yang cepat. Kurikulum harus dinamis, sesuai $\square$ 
dengan perkembangan sosial budaya. Kurikulum yang berbudaya adalah yang selalu dipelajari kembali sehingga sesuai dengan misi pendidikan dalam pembentukan kepribadian dan keahlian manusia (HAR. Tilaar: 1999). PTAIN sebagai perguruan tinggi setiap empat atau lima tahun sekali harus melakukan pengembangan kurikulum dalam bentuk peninjauan kurikulum.

Namun, peninjauan itu bukan hanya berdampak administratifformalistik, tetapi harus menjadi elan vital pengembangan kurikulum yang merespon perkembangan ilmu, pengetahuan, teknologi, dan kebutuhan real masyarakat pengguna jasa apendidikan tinggi. Masalah lebih khusus dalam pemberlakuan kurikulum di perguruan tinggi adalah yang terkait dengan kurikulum bidang penelitian yang diajarkan dan dilatihkan kepada mahasiswa. Karena itu diupayakan evaluasi untuk pengembangannya. Evaluasi terkadang kurang terukur sehingga evaluasi dilakukan tanpa standarisasi sesuai kurikulum yang ideal. Evaluasi sebagai komponen penting kurikulum juga sering tidak dirumuskan secara jelas, meskipun tidak semua aspek penilaian itu diukur dengan angka. Kejelasan standarisasi evaluasi pada rumusan kurikulum akan membantu upaya pencapaian tujuan melalui proses evaluasi yang valid dan reliabel.

Perguruan tinggi mempunyai fungsi utamanya sebagai lembaga khusus yang menangani sumber daya manusia di bidang keilmuan. Perguruan tinggi mempunyai tiga dharma, yang disebut sebagai Tri Dharma Perguruan Tinggi, yaitu dharma pendidikan, dharma penelitian, dan dharma pengabdian pada masyarakat. Perguruan tinggi mempunyai tugas utama dalam menyelenggarakan pendidikan tingkat tinggi. Ketiga dharma itu merupakan satu kesatuan integral yang tidak terpisah. Eksistensi sebuah kampus harus merepresentasikan ketiganya tanpa kecuali. Dengan demikian, kampus bukan hanya menjadi lembaga pendidikan, tetapi juga sebagai lembaga penelitian, dan juga lembaga pengabdian pada masyarakat.

Masalah lain dalam kurikulum adalah tentang isi kurikulum yang tidak sesuai dengan tujuan yang diharapkan. Isi kurikulum seharusnya merujuk pada rumusan tujuan atau sesuai dengan visi dan misi pendidikan. Kesenjangan ini harus diatasi dengan upaya penyesuaian terhadap tujuan. Komponen kurikulum (Nasution 1993: 3-4) yang terdiri dari tujuan, bahan 104 pelajaran, proses belajar mengajar dan penilaian harus dirumuskan secara 
serasi, selaras dan seimbang, baik untuk kurikulum nasional maupun kurikulum muatan lokal.

Namun, gejala di atas tidak menyeluruh. Perguruan tinggi tertentu mempunyaisisipersamaan dan perbedaan dalammengaplikasikan kurikulum bidang teaching and learning. Faktor-faktor persamaan dan perbedaan itu akan menjadi kajian yang menarik dalam penelitian ini. Sehingga, secara keilmuan penelitian ini mempunyai urgensi untuk dilaksanakan karena perguruan tinggi masa kini mengalami perkembangan dalam berbagai sendi, baik secara fisik maupun non-fisik, terutama perkembangan metode dan teknik teaching and learning.

Sisi lain yang melatarbelakangi penelitian ini adalah tentang kompetensi dalam pendidikan kajian keislaman yang tertampung pada PTAIN. Struktur dan karakteristik ilmu-ilmu yang dipelajari dan dikembangkan di perguruan tinggi pada umumnya bersifat terbuka, general dan belum membumi sehingga membutuhkan pengembangan dan pemberdayaan lebih lanjut. Upaya ini dalam satu sisi merupakan bagian dari sistem perencanaan institusional yang sudah dirumuskan sebelumnya, dan dalam sisi yang lain merupakan respon terhadap kebijakan baru kurikulum pendidikan di Indonesia yang berciri kurikulum berbasis kompetensi. Upaya-upaya pengembangan kurikulum di perguruan tinggi tersebut sangat menarik karena merupakan bidang penting dalam perkembangan pendidikan dewasa ini. Dengan berbagai alasan dan latar belakang di atas, penelitian ini dilakukan dengan tema manajemen kurikulum bidang penelitian.

\subsection{Fokus Penelitian}

Penelitian ini adalah tentang kurikulum bidang penelitian pada penyelenggaraan pendidikan sarjana, yang secara rinci difokuskan pada halhal sebagai berikut :

1.2.1. Bagaimana perencanaan kebijakan kurikulum bidang teaching and learning di Sekolah Tinggi Agama Islam Negeri Kudus?

1.2.2. Bagaimana silabi kurikulum bidang teaching and learning di Sekolah Tinggi Agama Islam Negeri Kudus?

1.2.3. Bagaimana satuan acara perkuliahan (SAP) kurikulum bidang 
teaching and learning di Sekolah Tinggi Agama Islam Negeri Kudus?

\subsection{Batasan Masalah}

Banyak masalah dalam hal berkaitan dengan kurikulum bidang penelitian pada perguruan tinggi agama Islam negeri (PTAIN), namun dalam penelitian ini dibatasi cakupan pembahasannya pada aspek: (1) perencanaan kebijakan kurikulum bidang teaching and learning di Sekolah Tinggi Agama Islam Negeri Kudus, (2) silabi kurikulum bidang teaching and learning di Sekolah Tinggi Agama Islam Negeri Kudus, (3) satuan acara perkuliahan (SAP) kurikulum bidang teaching and learning di Sekolah Tinggi Agama Islam Negeri Kudus .

\subsection{Tujuan Penelitian}

Penelitian ini lakukan dengan tujuan sebagai berikut :

1.4.1. Menjelaskan perencanaan kebijakan kurikulum bidang teaching and learning di Sekolah Tinggi Agama Islam Negeri Kudus.

1.4.2. Mendeskripsikan silabi kurikulum bidang teaching and learning di Sekolah Tinggi Agama Islam Negeri Kudus.

1.4.3. Mendeskripsikan satuan acara perkuliahan (SAP) kurikulum bidang teaching and learning di Sekolah Tinggi Agama Islam Negeri Kudus.

\subsection{Manfaat Penelitian}

Penelitian ini diharapkan dapat memberikan manfaat, baik secara teoritis maupun secara praktis sebagai berikut:

1.5.1. Manfaat teoritis penelitian ini adalah kajian tentang pengembangan kurikulum dalam ilmu pendidikan, yaitu pengembangan kurikulum bidang teaching and learning di perguruan tinggi agama Islam serta untuk memperkaya khazanah keilmuan dalam bidang pendidikan.

1.5.2. Manfaat praktis penelitian ini adalah memberikan informasi dan masukan kepada para pengelola dan pendidik, serta perguruan tinggi yang menyelenggarakan pendidikan tinggi, baik untuk mahasiswa, dosen, tenaga kependidikan, maupun pemerhati pendidikan tinggi pada umumnya. 


\section{Kajian Pustaka}

\subsection{Kurikulum}

Salah satu usaha peningkatan mutu mahasiswa adalah dengan menentukan kebijakan dan penerapan kurikulum, baik kurikulum umum maupun khusus di perguruan tinggi, termasuk kurikulum bidang teaching and learning. Kurikulum umum biasanya kurikulum tingkat perguruan tinggi, kurikulum lokal didesain dan diajarkan kepada mahasiswa dengan tujuan dan target pembelajaran.

\subsection{Kurikulum dan Pengembangannya}

\subsubsection{Kurikulum Perguruan Tinggi}

Menurut Subandijah (1996:2-3) dalam bukunya Pengembangan dan Inovasi Kurikulum, yang dimaksud kurikulum adalah "aktifitas dan kegiatan belajar yang direncanakan, diprogramkan bagi peserta didik di bawah bimbingan sekolah, baik di dalam maupun di luar sekolah". Isi definisi tersebut dapat diklasifikasi menjadi dua substansi, yaitu (1) kurikulum sebagai program yang direncanakan dan dilaksanakan di sekolah dan (2) kurikulum sebagai program yang direncanakan dan dilaksanakan secara nyata di kelas. Perencanaan program dan pelaksanaannya tersebut dimaksudkan untuk mencapai tujuan pendidikan yang telah ditetapkan. Dengan demikian, kurikulum berkedudukan sebagai alat untuk mencapai tujuan pendidikan.

Pendidikan tinggi di Indonesia melaksanakan proses pembelajaran dengan mengacu pada kurikulum nasional. Di samping itu, lembaga pendidikan juga menerapkan kurikulum muatan lokal yang ditentukan oleh masing-masing satuan lembaga pendidikan. Kedua macam kurikulum itu merupakan keharusan bagi setiap lembaga pendidikan untuk menerapkannya. Menurut UU RI No. 20 Tahun 2003, kurikulum pendidikan wajib memuat : pendidikan agama, pendidikan kewarganegaraan, bahasa, dan ilmu-ilmu dasar dan ilmu-ilmu terapan yang mendukung tujuan pendidikan masing-masing fakultas, jurusan, dan program studi.

Jadi di samping materi yang telah ditentukan secara nasional, sebuah lembaga pendidikan harus menentukan dan mengajarkan kurikulum muatan lokal yang didesain, diajarkan dan diujikan di lembaga pendidikan tersebut. 
Dalam hal ini, perguruan tinggi menerapkan suatu sistem kurikulum bidang teaching and learning karena termasuk dalam bidang terapan yang pasti digunakan oleh mahasiswa dalam membekalii ilmu pengetahuan dan keterampilannya.

\subsubsection{Pengembangan Kurikulum}

Pengembangan kurikulum menurut Hendyat Soetopo dan Wasty Soemanto (1986:41) adalah "kegiatan menghasilkan kurikulum baru melalui langkah-langkah penyusunan, pelaksanaan dan penyempurnaan kurikulum atas dasar hasil penilaian yang dilakukan selama kegiatan pengembangan tersebut". Sedang pengembangan kurikulum menurut Centre for Educational Research and Innovation (CERI) dalam rumusan Soetopo (1986:45) didefinisikan sebagai "curriculum development is the proces of analizing and refining goals, aims and objectives, together with the translation of these into the content of course by formal or informal methods“. Kegiatan pengembangan kurikulum meliputi penyusunan kurikulum, pelaksanaannya di dalam proses belajar mengajar dan penyempurnaan terhadap komponenkomponen tertentu atas dasar hasil penilaian.

\subsubsection{Landasan Pengembangan Kurikulum}

Menurut Nasution (1993:1-2), pengembangan kurikulum didasarkan atas asas-asas tertentu, yaitu : (1) asas filosofis yang pada hakekatnya menentukan tujuan umum pendidikan, (2) asas sosiologis yang memberikan dasar untuk menentukan apa yang akan dipelajari sesuai dengan kebutuhan masyarakat, budaya dan perkembangan ilmu pengetahuan dan teknologi, (3) asas organisatoris yang memberikan dasar-dasar dalam bentuk bagaimana bahan pelajaran disusun dan bagaimana luas dan urutannya, dan (4) asas psikologis yang memberikan prinsip-prinsip tentang perkembangan manusia dalam berbagai aspek serta cara belajar agar bahan yang disediakan dapat dicerna dan dikuasai peserta didik sesuai dengan taraf perkembangannya.

Hendyat Soetopo dan Wasty Soemanto (1986 : 46) menerangkan bahwa landasan pengembagan kurikulum dapat menjadi "titik tolak" sekaligus menjadi "titik sampai". Titik tolak berarti pengembangan 
kurikulum dapat didorong oleh pembaharuan tertentu seperti penemuan teori belajar yang baru dan perubahan tuntutan masyarakat terhadap fungsi lembaga pendidikan. Titik sampai berarti kurikulum harus dikembangkan sedemikian rupa sehingga dapat merealisasikan perkembangan tertentu, seperti dampak kemajuan ilmu pengetahuan dan teknologi, tuntutantuntutan sejarah masa lalu, perbedaan latar belakang peserta didik, nilainilai filsafat suatu masyarakat dan tuntutan-tuntutan kultur tertentu.

\subsubsection{Perencanaan Kurikulum}

Perencanaan menurut St. Vembriarto (1993:28) dalam bukunya Pengantar Perencanaan Pendidikan adalah penggunaan analisis yang bersifat rasional dan sistematis terhadap proses pengembangan pendidikan yang bertujuan untuk menjadikan pendidikan lebih efektif dan efisien dalam menanggapi kebutuhan dan tujuan peserta didik dan masyarakat.

Ada empat persoalan penting yang dibahas dalam perencanaan, yaitu (1) tujuan apa yang dicapai dengan perencanaan itu, (2) status sistem pendidikan yang ada dan bagaimana keadaannya sekarang, (3) kemungkinan-kemungkinan pilihan apa yang ditempuh untuk mencapai tujuan, dan (4) strategi yang terbaik untuk mencapai tujuan.

Jadi perencanaan dalam pendidikan adalah sebagai fungsi manajemen pendidikan. Fungsi perencanaan tersebut adalah untuk menentukan keadaan yang sebaik-baiknya dari hubungan-hubungan sumber daya internal dan eksternal dalam suatu sistem pendidikan dengan keadaaan yang dinamis serta cara yang efisien dan efektif untuk mencapai tujuan yang diinginkan.

Salah satu sumber daya yang harus direncanakan adalah "materi pendidikan" atau kurikulum. Sumber daya "kurikulum" ini membutuhkan perencanaan yang tepat dan strategis. Hasil perencanaan kurikulum yang baik menentukan keberhasilan dalam pencapaian tujuan pendidikan. Dalam konteks perkembangan, kurikulum harus selalu dikembangkan. Fungsi perencanaan kurikulum dan pengembangnnya itu dimaksudkan untuk pengelolaan pendidikan agar tidak mengalami ketertinggalan. 


\subsubsection{Faktor-faktor Pengembangan Kurikulum}

Soetopo (1986:40-41) mengemukakan tiga faktor umum yang mendorong pengembangan kurikulum, yaitu (1) perubahan yang diinginkan masyarakat sehingga mereka merencanakan adanya perubahan yang cukup penting di dalam kurikulum dan sistem pendidikan, (2) perkembangan ilmu pengetahuan dan teknologi yang pesat, dan (3) pertambahan pesat penduduk dunia.

Menurut Nasution (1993:159) dalam bukunya Pengembangan Kurikulum, proses pengembangan kurikulum dijalankan karena (1) hasil penelitian dan pengembangan, (2) interaksi sosial, dan (3) metode pemecahan masalah.

\subsubsection{Prinsip-prinsip Pengembangan Kurikulum}

Menurut Soetopo (1986:48), prinsip-prinsip dasar pengembangan kurikulum meliputi : (1) prinsip relevansi, yang meliputi relevansi dengan lingkungan, perkembangan masa dan tuntutan dunia kerja, (2) prinsip efektifitas yang meliputi efektifitas mengajar pendidik dan efektifitas belajar peserta didik, (3) prinsip efisiensi dalam penggunaan sumber daya pendidikan.

Prinsip-prinsip pengembangan kurikulum menurut Subandijah (1993:48) adalah : (1) prinsip relevansi, (2) prinsip efektifitas dan efisiensi, (3) prinsip kesinambungan, (4) prinsip fleksibilitas, (5) prinsip berorientasi pada tujuan, (6) prinsip pendidikan seumur hidup, dan (6) prinsip kesesuaian dengan model pengembangan kurikulum.

\subsubsection{Pendekatan dan Model Pengembangan Kurikulum}

Pendekatan dalam pengembangan kurikulum diorientasikan pada (1) tujuan pendidikan dan (2) bahan pelajaran. Subandijah (1993:55) mengemukakan tiga pendekatan dengan pola organisasi bahan sebagai berikut : (1) pendekatan dengan pola subject matter curriculum, yaitu pendekatan yang menekankan pada mata pelajaran/mata kuliah secara terpisah-pisah, (2) pendekatan dengan pola corelated curriculum, yaitu pendekatan dengan pola pengelompokan beberapa mata kuliah yang seiring 
(serumpun), dan (3) pendekatan dengan pola integrated curriculum, yaitu pendekatan dengan penyatuan keseluruhan mata kuliah sebagai bahan ajar yang sistematik-integralistik.

\subsubsection{Tahap-tahap Pengembangan Kurikulum}

Langkah-langkah utama dalam perencanaan kurikulum --misalnya dengan model Tyler dalam Nasution (1993:140) — meliputi (1) menentukan tujuan pendidikan, (2) menentukan proses belajar mengajar, (3) menentukan organisasi kurikulum, dan (4) menentukan cara penilaian hasil belajar.

Adapun tahap-tahap dalam pengembangan kurikulum menurut Subandijah (1993:215) adalah : (1) pengembangan kurikulum pada tingkat lembaga, (2) pengembangan kurikulum pada tingkat/setiap bidang studi, dan (3) pengembangan pengajaran di kelas.

Tahap-tahap pengembangan kurikulum di perguruan tinggi dijalani secara terstruktur, sepanjang masa dari tahun ke tahun selama satu periode pemberlakuan kurikulum berkisar antara 4 hingga 5 tahun. Menurut Keputusan Menteri Pendidikan Nasional Nomo 232/U/2000, kurikulum pada perguruan tinggi untuk program sarjana (S1) berkisar antara $144 \mathrm{~s} / \mathrm{d}$ 160 sks, sedangkan untuk program magister (S2) berkisar 36 s/d 50 sks, dan untuk program doktor (S3) berkisar $40 \mathrm{~s} / \mathrm{d} 52$ sks.

\section{Metode Penelitian}

\subsection{Pendekatan Penelitian}

McMillan (2001:29) menjelaskan bahwa penelitian dengan pendekatan kualitatif mempunyai beberapa model, yaitu etnografi, fenomenologi, studi kasus, grounded theory, critical studies, concept analysis dan historical analysis.

Model yang digunakan dalam penelitian ini adalah deskripsi dengan satu lokasi penelitian di STAIN Kudus. Karakter utama dari pendekatan kualitatif adalah bukan dimaksudkan untuk menguji suatu teori, tetapi untuk mengungkapkan fenomena dan realitas melalui data-data secara deskriptif. Data-data spesifik dicari maknanya untuk membuat kesimpulan yang general dari makna-makna yang diperoleh dari data-data tersebut. 
Penelitian ini dirancang untuk menjelaskan tentang konsep kurikulum bidang teaching and learning di STAIN Kudus.

\subsection{Subyek dan Sumber Penelitian}

Sumber informasi utama dalam penelitian ini adalah dokumentasi kurikulum pada STAIN Kudus. Untuk memperoleh data yang absah, sumber informasi ditentukan secara purposif, yaitu para responden yang dianggap bisa memberikan data yang akurat, maka dituju sebagai sumber yang pokok. Peneliti mengklasifikasi sumber-sumber tersebut dalam pembagian bidang yang diteliti.

\subsection{Lokasi dan Waktu Penelitian}

Agar diperoleh kesesuaian antara persoalan yang fokus dengan setting penelitian, sebagaimana dianjurkan oleh Moleong (1994), dilakukan penjajakan dan penilaian lapangan, dalam hal ini adalah pada STAIN Kudus yang sedang mengembangkan kurikulum. Penelitian dengan pendekatan kualitatif tidak ditentukan batas waktu secara jelas sampai peneliti memperoleh pemahaman yang benar-benar mendalam tentang obyek yang diteliti. Namun karena pertimbangan dan keterbatasan waktu, biaya dan tenaga, maka penelitian dapat diakhiri dan dibuat laporannya jika dianggap telah mencapai data dan analisis sesuai dengan rancangan.

\subsection{Teknik Pengumpulan Data}

Untuk pengumpulan data, penelitian ini menggunakan beberapa teknik, yaitu pengamatan/observasi dan dokumentasi. Mestinya, focus group discussion (FGD) juga digunakan dengan tujuan menemukan makna sebuah tema menurut pemahaman kelompok (Bungin 2003). FGD juga dimaksudkan untuk menarik kesimpulan terhadap makna-makna intersubyektif yang sulit dimaknai sendiri oleh peneliti karena keterbatasan informasi sehingga

$\varangle$ mendapat obyektifitas dari peserta diskusi. Namun, dominasi pengumpulan data dari dokumen.

Dalam pengamatan, dua hal penting (Nasution 1996:58) yang diperhatikan, yaitu informasi dan konteks. Dengan ketepatan dalam 
menghubungkan keduanya, maka didapat maknanya, karena makna diperoleh dari keterkaitan antara informasi dan konteksnya. Bentuk pengamatan yang dilakukan dalam penelitian ini ada tiga, yaitu : (1) pengamatan secara deskriptif, (2) pengamatan secara terfokus, dan (3) pengamatan selektif.

Dokumentasi dilakukan untuk mendapatkan informasi dari sumber yang berupa dokumen/arsip, foto, dan bahan statistik yang lain. Data diperoleh dari dokumentasi data-data, baik yang berupa tulisan/dokumen resmi maupun dokumen pribadi seperti makalah, artikel, catatan dan suratsurat, misalnya buku panduan, buku laporan, buku laporan dan sebagainya.

\subsection{Keabsahan Data}

Agar data yang diperoleh, yang berujung pada kesimpulan atau verifikasi, dapat dipertanggungjawabkan secara ilmiah, maka dilakukan pemeriksaan keabsahan data. Teknik yang digunakan dalam pemeriksaan keabsahan data dalam penelitian ini, sebagaimana dikatakan Moleong (2001) meliputi : perpanjangan keikutsertaan, ketekunan pengamatan, triangulasi, pemeriksaan sejawat, kecukupan referensi, kajian kasus negatif dan pengecekan. Namun, dalam penelitian ini, tidak semua teknik di atas digunakan, hanya beberapa teknik yang tepat dan diperlukan saja yang digunakan. Untuk pengecekan keabsahan data menggunakan empat kriteria Moleong (2001), yaitu derajat kepercayaan (credibility), keteralihan (transferablity), kebergantungan (dependability) dan kepastian (confirmability).

\subsection{Teknik Analisis Data}

Analisis data merupakan proses mencari dan mengatur secara sistematis transkrip wawancara, cacatan lapangan, dan bahan-bahan lain yang telah dihimpun untuk menambah pemahaman menganai bahan-bahan penelitian untuk memungkinkan mendapat temuan sebagai hasil penelitian (Bogdan 1990). Untuk memberikan pemaknaan atas data atau fenomena yang ditemukan dan dikumpulkan dalam penelitian ini, maka dilakukan analisis dengan pendekatan kualitatif dengan eksplanasi bersifat deskripsi. Dengan teknik analisis deskriptif, langkah yang ditempuh dalam analisis 
ini adalah mengorganisir data berupa gambar, foto, dokumen yang berupa laporan, biografi, artikel, buku-buku pedoman dan sebagainya (Moleong, 2001 : 103). Selanjutnya data-data yang diperoleh dianalisis dengan model siklus interaktif sebagaimana dikemukakan oleh Milles dan Huberman (1992 : 20).

\section{Hasil Penelitian}

\section{Deskripsi tentang Perencanaan Kurikulum Bidang Teaching and Learning}

Berdasarkan data yang dihimpun, perencanaan kurikulum pada program pendidikan agama Islam Sekolah Tinggi Agama Islam Negeri Kudus dilakukan penyusunan secara periodik mulai kurikulum 1997, kurikulum 2003, dan kurikulum 2008, hingga kurikulum 2013. Kurikulum dari tiga periode itu dilakukan evaluasi dan penyusunan kembali hingga melibatkan para dosen dan ahli, baik dari dalam lembaga maupun ahli dari luar. Kurikulum 2008 disusun dengan mengacu pada Keputusan Menteri Pendidikan Nasional Nomor 232/U/2000 tentang Pedoman Penyusunan Kurikulum Pendidikan Tinggi dan Penilaian Hasil Belajar Mahasiswa. Jadi, kurikulum 2008 bisa disebut kurikulum dengan pendekatan dengan pola corelated curriculum yang berbasis pada kompetensi, yaitu pendekatan dengan pola pengelompokan beberapa mata kuliah yang seiring (serumpun). Artinya, kurikulum 2008 ini tidak kurikulum yang berpendekatan dengan pola subject matter curriculum, atau pendekatan yang menekankan pada mata pelajaran/mata kuliah secara terpisah-pisah. Dari sini, kurikulum STAIN Kudus Tahun 2008 sudah melangkah lebih maju. Namun, tantangan ke depan untuk STAIN Kudus, para perencana kurikulum sebaiknya mempertimbangkan suatu pendekatan dengan pola integrated curriculum, yaitu pendekatan dengan penyatuan keseluruhan mata kuliah sebagai bahan ajar yang sistematik-integralistik. Temuan penelitian ini meliputi : (1)Perencanaan kurikulum di STAIN Kudus menggunakan pendekatan dengan berbasis kompetensi, yaitu pendekatan dengan memastikan mata kuliah sebagai bahan ajar yang berorientasi pada kemampuan peserta didik/mahasiswa, dengan tiga mata kuliah yang bernuansa teaching and 114 learning, yaitu Perencanaan Sistem Pendidikan Agama Islam, Strategi 
Pembelajaran Pendidikan Agama Islam, dan Pengembangan Sistem Evaluasi Pendidikan Agama Islam, (2) Silabi ketiga mata kuliah serumpun bidang teaching and learning yaitu Perencanaan Sistem Pendidikan Agama Islam, Strategi Pembelajaran Pendidikan Agama Islam, dan Pengembangan Sistem Evaluasi Pendidikan Agama Islam itu berbeda secara jelas dari aspek ruang lingkupnya, namun disatukan secara integratif dari aspek penguasaan metode dan teknik pembelajaran, (3) Satuan acara perkuliahan untuk ketiga mata kuliah rumpun bidang teaching and learning, yaitu Perencanaan Sistem Pendidikan Agama Islam, Strategi Pembelajaran Pendidikan Agama Islam, dan Pengembangan Sistem Evaluasi Pendidikan Agama Islam itu disusun dengan komponen kode mata kuliah, kelompok jenis mata kuliah, program studi, strata kesarjanaan, bobot sistem kredit semester, banyak pertemuan empat belas kali, waktu sesuai bobot kredit, standar kompetensi, kompetensi dasar, indikator, materi pokok, metode pembelajaran, sistem penilaian, serta bahan dan sumber belajar.

\section{Penutup}

Kurikulum pada perguruan tinggi yang mengajarkan peserta didiknya untuk mampu melakukan tindakan teaching and learning yaitu Perencanaan Sistem Pendidikan Agama Islam, Strategi Pembelajaran Pendidikan Agama Islam, dan Pengembangan Sistem Evaluasi Pendidikan Agama Islam, memerlukan strategi khusus agar semakin kontekstual dengan perkembangan metodologi dan isu-isu hangat bidang pendidikan. Jenis-jenis dan strategi teaching and learning yang semakin luas dan kaya menyarankan agar kurikulum bidang teaching and learning di perguruan tinggi menentukan berbagai spesifikasinya sesuai bidang dan program yang diancangkan di perguruan tinggi. 


\section{DAFTAR PUSTAKA}

Buku Pedoman Akademik Sekolah Tinggi Agama Islam Negeri Kudus.

Bungin, Burhan. 2003. Analisis Data Penelitian Kualitatif: Pemahaman Filososfis dan Metodologis ke Arah Penguasaan Model Aplikasi. Jakarta:PT. RajaGrafindo Persada.

De Vos. 1987. Pengantar Etika (terjemahan) Soejono Soemargono. Yogyakarta:Tiara Wacana.

Denzin, Norman, K and Lincold, Yvonna S. 2000. Handbook of Qualitative Research (Second Edition). California:Sage Publication, Inc.

Matthew, Miles B, dan Huberman. 1992. Analisis Data Kualitatif. Terjemahan Tjetjep Rohendi. Jakarta: Universitas Indonesia.

McMillan, James H and Sally Schumacher. 2001. Research In Education A Conceptual Introduction. San Francisco: Longman.

Moleong, Lexy, J. 2000. Metodologi Penelitian Kualitatif. Yogyakarta: Rake Sarasin.

Nasution, S,. 1993. Pengembangan dan Inovasi Kurikulum. Jakarta: PT. Citra Aditya Bakti.

Nasution, S,. 1996. Metode Penelitian Naturalistik Kualitatif. Bandung: Tarsito.

Nizar, Samsul. 2002. Filsafat Pendidikan Islam Pendekatan Historis, Teoritis, dan Praktis. Jakarta:Ciputat Press.

Poedjawiyatna. 1985. Etika : Filsafat Tingkah Laku. Jakarta:Rineka Cipta.

Praja, Juhaya S. 1997. Aliran-aliran Filsafat dan Etika. Bandung:Tiara.

Robbins, Stephen P. 2008. Perilaku Organisasi (Edisi Kesepuluh). Terjemahan Benyamin Molan. Indonesia:Indeks.

Rofiq, Moh. 2009. Ilmu Pendidikan Islam Pengembangan Pendidikan Integratif di Sekolah, Keluarga, dan Masyarakat. Yogyakarta:LKiS.

Salam, Burhanuddin. 2000. Etika Individual : Pola Dasar Filsafat Moral. Jakarta:Rineka Cipta.

Satmoko, Retno, Sriningsih. 1999. Landasan Kependidikan : Pengantar ke Arah Ilmu Pendidikan Pancasila. Semarang: CV. IKIP Semarang Press. Soetopo, Henyat dan Soemanto, Wasty. 1986. Pembinaan dan Pengembangan 
Subandijah. 1996. Pengembangan dan Inovasi Kurikulum. Jakarta: PT. Raja Grafindo Persada.

Sudarminta. 1991. Filsafat Proses : Sebuah Pengantar Sistematika Filsafat Alfred North Whitehead. Yogayakarta:Kanisius.

Sugiyono. 2008. Metode Penelitian Pendidikan Pendekatan Kuantitatif, Kualitatif dan R \& D. Bandung:Alfabeta.

Suseno, Franz Magnis. 1987. Etika Dasar. Yogyakarta:Kanisius.

Tilaar, HAR. 1999. Pendidikan, Kebudayaan dan Masyarakat Madani Indonesia. Bandung: PT. Remaja Rosda Karya.

Tjiptono, Fandy dan Anastasia Diana. 2000. Total Quality Manaaagement. Yogyakarta:Penerbit Andi

UU RI No. 20 Tahun 2003 tentang Sistem Pendidikan Nasional

UU RI No. 12 Tahun 2012 tentang Pendidikan Tinggi

Vembriarto, St,. 1993. Pengantar Perencanaan Pendidikan. Jakarta: PT. Grasindo. 